\title{
HUBUNGAN KECERDASAN EMOSIONAL DENGAN PERILAKU MENARIK DIRI PADA PERAWAT WANITA
}

\author{
Tri Ismu Pujiyanto, Achmad Syaifudin, Laras Sri Sayekti \\ Prodi S1 Keperawatan, STIKes Karya Husada Semarang Jl. Kompol R. Soekanto No. 46 Semarang \\ Email: achmad.yahoed@gmail.com
}

\begin{abstract}
ABSTRAK
Emosi merupakan kekuatan psikologis yang secara signifikan dapat mempengaruhi perilaku dan kinerja tenaga perawat dalam hal ini adalah perawat wanita. Selain sebagai perawat, ia juga berperan dalam keseharian di dalam keluarganya. Kemampuan beradaptasi dalam menjalankan aktivitas adalah penting. Penelitian ini bertujuan untuk mengetahui hubungan antara kecerdasan emosional dengan perilaku menarik diri pada perawat perempuan di RSUD Ungaran. Metode penelitian menggunakan metode penelitian korelasional dengan desain pendekatan cross-sectional. Populasi penelitian sebanyak 78 responden dengan teknik pengambilan sampel purposive sampling diperoleh sampel 65 responden perawat wanita. Hasil menunjukkan perawat wanita di RSUD Ungaran memiliki kecerdasan emosional yang baik $(63,1 \%)$, dan tidak mengalami perilaku menarik diri $(66,2 \%)$. P-value $0,000<0,05$ menyatakan ada hubungan antara kecerdasan emosional dengan perilaku menarik diri. Kesimpulan : kemampuan adaptasi seseorang memiliki pengaruh dalam aktivitas sehari hari, dengan kecerdasan emosional yang baik perawat dituntut menjalankan kewajiban profesionalnya sebagai perawat dengan baik.
\end{abstract}

Kata kunci: kecerdasan emosional; perilaku menarik diri; perawat wanita

\section{THE RELATION OF EMOTIONAL INTELLIGENCE AND SELF-ATTRACTIVE BEHAVIOR IN FEMALE NURSE}

\begin{abstract}
Emotion is a psychological force that can significantly influence the behavior and performance of nurses, in this case female nurses. In addition to being a nurse, they also play a role in daily life in their family. Adaptability to carry out activities is important. This research aim was to find out the link between emotional intelligence and self-attractive behavior in female nurses at Ungaran Hospital. This study used correlational research methods. The design of this study used a crosssectional approach. The study's population of 78 respondents with purposive sampling techniques was obtained by 65 female nurse respondents. Female nurses at Ungaran Hospital are in good emotional intelligence (63.1\%), and did not experience of self-attractive behavior (66.2\%). P-value $0.000<0.05$ then it can be concluded that there is a meaningful relationship between emotional intelligence and the behavior of self-attractive. A person's adaptability has an influence in daily activities, with good emotional intelligence the nurse is required to carry out his professional duties as a nurse properly.
\end{abstract}

Keywords: emotional intelligence; self-attractive behavior; female nurse

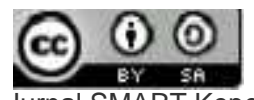

Jurnal SMART Keperawatan is licensed under a Creative Commons Attribution-ShareAlike 4.0 International License 


\section{LATAR BELAKANG}

Perempuan pada dasarnya lebih mengalami konflik dalam bekerja dibanding laki-laki, karena perempuan mempunyai peran yang berbeda dalam keluarga.(Handayani et al., 2015) Konflik peran ganda pada perawat wanita merupakan suatu hal yang dialami oleh perawat wanita dalam hal ini, saat menjalankan tugas lebih dari satu peran sekaligus. Sebagai perawat, tugasnya dalam memberikan asuhan keperawatan secara professional telah di atur dalam undang undang, dan kode etik profesi.(PPNI, n.d.)

Perawat wanita dalam kehidupan manusia adalah yang menarik karena perannya yakni sebagai individu, istri, ibu hingga kompleks pada peran sebagai perawat. (Sari, n.d.) Wanita dalam hal ini perawat wanita, perannya di dalam rumah tangga yang penting mulai mengasuh anak dan mengelola rumah tangga menuntut wanita harus pintar dan membagi waktu dengan baik (Yunita \& Fauziah, 2017) menjaga keseimbangan pekerjaan tersebut, hingga tidak memungkiri dapat terjadi konflik ketika seorang perawat wanita bekerja dan dapat berimbas pada kinerja yang dihasilkan (Yunita \& Fauziah, 2017). Hal tersebut juga miliki efek dalam sebuah pelayanan asuhan keperawatan yang berkualitas secara tidak langsung berkaitan dengan kualitas kehidupan kerja perawat itu sendiri (Tri Ismu Pujiyanto, 2020).

Kualitas kinerja yang dihasilkan dengan banyaknya pekerjaan yang dilakukan, tidak mudah tanpa adanya kecerdasan emosional yang cukup. Begitu pula dalam pekerjaan keperawatan dimana pekerjaan sangat memerlukan keahlian dan keterampilan untuk memenuhi kebutuhan pasien yang mencakup kebutuhan biologis, psikologis, sosiologis dan spiritual pasien sehingga untuk dapat terpenuhinya pelayanan yang komprehensif diperlukan kemampuan mengelola emosi dengan baik karena perawat juga termasuk pekerjaan yang menimbulkan resiko stress yang tinggi (Goleman, 2004).

Kemampuan dalam menghadapi tantangan dan menjadi pribadi yang bertanggung jawab terhadap pekerjaan, diperlukan oleh perawat dalam mengelola pekerjaan dengan baik. Kemampuan mengontrol emosional individu perawat

Salah satu dimensi dalam meningkatkan kualitas pekerjaan perawat adalah karakter. Selain karakter tersebut, pada orde baru saat ini kecerdasan otak saja masih dipandang belum maksimal. Kecerdasan lain seperti kecerdasan emosional jauh berperan lebih penting (Mulyasari, 2019). Kecerdasan emosional mampu menghadapi tantangan dan menjadikan seorang manusia yang penuh tanggung jawab, produktif dan optimis dalam menghadapi dan menyelesaikan masalah yang ternyata sangat diperlukan di dalam lingkungan kerja sehingga menuntut perawat untuk professional dalam bekerja (Mangkunegara, 2012)

Keprofesionalan yang terlihat dalam pekerjaan perawat dapat ditunjukkan mulai dari pekerjaan yang diselesaikan pada waktunya, dokumentasi asuhan yang optimal. Hal tersebut tampak belum optimal terlihat dari perawat dalam studi pendahuluan bahwa masih adanya perawat yang datang tidak tepat waktu, dokumentasi askep yang belum lengkap. Hasil wawancara perawat mengatakan masih belum optimalnya membagi waktu antara pekerjaan rumah yang banyak dengan pekerjaan, kadang lebih memilih berdiam untuk mampu menyelesaikan masalah dengan baik. Penelitian ini dilakukan untuk mengetahui hubungan antara kecerdasan emosional dengan perilaku menarik diri pada perawat perempuan di RSUD Ungaran.

\section{METODE}

Penelitian ini adalah studi kuantitatif, dengan metode penelitian korelasional. Populasi perawat perempuan yang sudah menikah bertugas di ruang rawat inap RSUD Ungaran Kabupaten Semarang sejumlah 78 responden. Menggunakan teknik purposive sampling yang diperoleh oleh 65 responden dengan kriteria inklusi Responden memiliki anak prasekolah hingga sekolah, Responden tinggal satu rumah dengan keluarga inti (suami, istri, anak). Instrumen dalam penelitian ini terdiri dari tiga 
bagian, yang pertama berisi pertanyaan tentang karakteristik responden, yang kedua tentang tentang kecerdasan emosional. Kuesioner kecerdasan emosional terdiri dari 10 pertanyaan dan yang ketiga tentang menarik perilaku. Kuesioner perilaku yang menarik terdiri dari 15 pertanyaan. Analisis data dalam penelitian ini menggunakan tes statistik ChiSquare dengan nilai probabilitas tingkat makna (95\%) di mana $(p=0.05)$. Penelitian ini dinyatakan telah lulus tinjauan etik oleh Komite Etika Penelitian STIKES Karya Husada Semarang Nomor : 479/KH.KEPK/KT/IV/2019.

\section{HASIL}

\section{Kecerdasan Emosional Perawat Wanita}

Tabel 1 distribusi frekuensi kecerdasan emosional pada perawat wanita

\begin{tabular}{lll}
\hline $\begin{array}{l}\text { Kecerdasan } \\
\text { emosional }\end{array}$ & Frekuensi & Presentase \\
\hline Kurang Baik & 24 & $36,9 \%$ \\
Baik & 38 & $63,1 \%$ \\
\hline Jumlah & 65 & $100 \%$ \\
\hline
\end{tabular}

Berdasarkan Tabel 1. dapat diketahui bahwa sebagian besar perawat wanita di RSUD Ungaran Kabupaten Semarang mempunyai kecerdasan emosional yang baik sebanyak 41 responden $(63,1 \%)$ dan sebagian kecil mempunyai kecerdasan emosional yang kurang baik sebanyak 24 responden (36,9\%)

\section{Perilaku Menarik Diri yang terjadi pada pekerja perawat wanita}

Tabel 2 Distribusi frekuensi perilaku menarik diri yang terjadi pada pekerja perawat wanita

\begin{tabular}{lcc}
\hline $\begin{array}{l}\text { Perilaku menarik } \\
\text { diri }\end{array}$ & Frekuensi & Presentase \\
\hline Kurang Baik & 22 & $33,8 \%$ \\
Baik & 43 & $66,2 \%$ \\
\hline Jumlah & $\mathbf{6 5}$ & $\mathbf{1 0 0 \%}$ \\
\hline
\end{tabular}

Berdasarkan Tabel 2. dapat diketahui bahwa sebagian besar perawat wanita di RSUD
Ungaran tidak mengalami perilaku menarik diri sebanyak 43 responden $(66,2 \%)$ dan sebagian kecil mengalami perilaku menarik diri sebanyak 22 responden $(33,8 \%)$.

\section{Hubungan kecerdasan emsional dengan perilaku menarik diri pada perawat}

Tabel 4. Analisa hubungan kecerdasan emosioanl dengan perilaku menarik diri pada perawat wanita

\begin{tabular}{|c|c|c|c|c|c|c|c|}
\hline \multirow{3}{*}{$\begin{array}{l}\text { Kecerdasan } \\
\text { emosional }\end{array}$} & \multicolumn{4}{|c|}{ Perilaku Menarik Diri } & & & \multirow{3}{*}{$\begin{array}{c}P \\
\text { value }\end{array}$} \\
\hline & \multicolumn{2}{|c|}{$\begin{array}{c}\text { Kurang } \\
\text { baik }\end{array}$} & \multicolumn{2}{|c|}{ Baik } & \multicolumn{2}{|c|}{ Total } & \\
\hline & $f$ & $\%$ & $f$ & $\%$ & $f$ & $\%$ & \\
\hline Kurang baik & 15 & 62.5 & 9 & 33,3 & 27 & 100 & 0.000 \\
\hline Baik & 7 & 17,1 & 34 & 89,5 & 38 & 100 & \\
\hline Jumlah & 22 & 33,8 & 43 & 66,2 & 16,5 & 100 & \\
\hline
\end{tabular}

Berdasarkan tabel silang tersebut diatas maka dapat diketahui bahwa perawat wanita di RSUD Ungaran Kabupaten Semarang yang mempunyai kecerdasan emosional yang kurang baik sebagian besar mengalami perilaku menarik diri sebanyak 15 responden $(62,5 \%)$ dan perawat wanita yang mempunyai kecerdasan emosional yang baik sebagian besar tidak mengalami perilaku menarik diri sebanyak 34 responden (82,9\%). $P$ value 0,000 menyatakan ada hubungan yang bermakna antara kecerdasan emosional dengan perilaku menarik diri pada perawat wanita

\section{PEMBAHASAN}

Bekerja berdampingan dengan waktu, menyelaraskan waktu dan tenaga untuk menjalankan peran, perawat merupakan sumber daya manusia yang berperan dalam memberikan pelayanan asuhan keperawatan di sebuah rumah sakit. Penting bahwa sebuah pelayanan tersebut, ada factor utama sebagai pelaku utama yakni perawat.

Kemampuan diri perawat tersebut dapat terlihat dari maksimalnya perawat bekerja. Terlihat dari perilaku yang dilakukan perawat 
dalam menjalankan aktivitas sebagai perawat pemeberi asuhan keperawatan. Perilaku yang baik di dukung dari motivasi dan keyakinan, tanpa keyakinan perawat tidak maksimal dalam bekerja atau bahkan tidak melakukan apa apa (Vaughan-Johnston \& Jacobson, 2020). Selain itu, factor pekerjaan seperti beban kerja yang dimiliki perawat tidak lain dari fisik dan mental, (Nofriyaldi \& Ratnaningsih, 2020) menjadikan perawat tetap menjalankan kewajibannya dengan terampil, tanggung jawab terhadap kesembuhan pasien hingga mengurus keluarga dari pasien serta masih berhadapan dengan kondisi lungkungan kerja yang beragam. Tuntutan pekerjaan tersebut mengharuskan perawat tetap menjaga emosinya dan memberikan pelayanan secara optimal dan seimbang dengan peran yang dijalaninya dalam rumah tangga atau keluarganya sendiri (Nursalam, 2014).

Kecerdasan emosional dalam pekerjaan keperawatan sangat diperlukan. Kecerdasan emosional adalah kemampuan untuk mengendalikan hal-hal negatif seperti kemarahan dan keragu-raguan atau rasa kurang percaya diri dan kemampuan untuk memusatkan perhatian pada hal-hal positif seperti rasa percaya diri dan keharmonisan dengan orang-orang di sekeliling (Goleman D, 2004).

Hasil penelitian menunjukkan bahwa sebagian besar perawat wanita di RSUD Ungaran Kabupaten Semarang memiliki kecerdasan emoional yang baik. Hanya sebagian kecil perawat yang mempunyai kecerdasan emosional yang kurang baik. Semakin banyak pekerjaan yang harus dilakukan, semakin penting kecerdasan emosional yang diperlukan. Begitu pula dalam pekerjaan keperawatan dimana pekerjaan sangat memerlukan keahlian dan keterampilan untuk memenuhi kebutuhan pasien yang mencakup kebutuhan biologis, psikologis, sosiologis dan spiritual pasien sehingga untuk dapat terpenuhinya pelayanan yang komprehensif diperlukan kemampuan mengelola emosi dengan baik karena perawat juga termasuk pekerjaan yang menimbulkan resiko stress yang tinggi. Kecerdasan emosional mencakup optimisme, fleksibilitas, dan kemampuan menangani stres dan memecahkan berbagai masalah, serta kemampuan memahami perasaan orang lain dan memlihara hubunganhubungan antar pribadi yang memuaskan (Craig AJ, 2004). Kecerdasan emosi dapat diukur dari beberapa aspek yang dalam kecerdasan emosi, yaitu mengenali emosi diri, mengelola emosi diri, memotivasi diri, mengetahui emosi orang lain dan membina hubungan baik dengan orang lain.

Mangkunegara menyatakan bahwa kecerdasan emosi menyumbang 80\% dari faktor penentu kesuksesan seseorang, sedangkan 20\% yang lain ditentukan oleh IQ Dengan demikian kecerdasan emosi berpengaruh terhadap kinerja pegawai. Orang yang memiliki kecerdasan emosi akan mampu menghadapi tantangan dan menjadikan seorang manusia yang penuh tanggung jawab, produktif dan optimis dalam menghadapi dan menyelesaikan masalah yang ternyata sangat diperlukan di dalam lingkungan kerja (Mangkunegara, 2006).

Kemampuan dan keyakinan perawat yang tinggi dapat mempengaruhi berfikir dan tindakan yang posisitf. Cara perawat dalam melihat individunya secara utuh mulai dari fisik, emosi, intelektual hingga social termasuk potensi dalam individu dan interaksi dengan lingkungan. (Suryalaga, 2020)

Dibutuhkan kecerdasan emosional yang baik agar perawat wanita dapat menyelesaikan dua tanggung jawab pekerjaan tersebut. (Sim et al., 2009) Semakin banyak pekerjaan yang harus dilakukan, semakin penting kecerdasan emosional yang diperlukan. Begitu pula dalam pekerjaan keperawatan dimana pekerjaan sangat memerlukan keahlian dan keterampilan untuk memenuhi kebutuhan pasien yang mencakup kebutuhan biologis, psikologis, sosiologis dan spiritual pasien sehingga untuk dapat terpenuhinya pelayanan yang komprehensif diperlukan kemampuan mengelola emosi dengan baik karena perawat juga termasuk pekerjaan yang menimbulkan resiko stress yang tinggi.(Marga \& Sintaasih, 2017) 


\section{KESIMPULAN DAN SARAN}

Kecerdasan emosional mencakup optimisme, fleksibilitas, dan kemampuan menangani stres dan memecahkan berbagai masalah, serta kemampuan perawat dalam menjalan aktivitasnya dalam memberikan asuhan keperawatan. Kecerdasan emosi dapat diukur dari beberapa aspek yang dalam kecerdasan emosi, yaitu mengenali emosi diri, mengelola emosi diri, memotivasi diri, mengetahui emosi orang lain dan membina hubungan baik dengan orang lain. Kecerdasan emosional yang baik, memiliki dampak yang baik terhadap perilaku yang dialami perawat terutama dalam kinerjanya sebagai pemberi asuhan keperawatan menjadikan seorang perawat yang penuh tanggung jawab, produktif dan optimis dalam menghadapi dan menyelesaikan masalah yang ternyata sangat diperlukan di dalam lingkungan kerja.

\section{REFERENSI}

Goleman, D. (2004). Primal leadership: kepemimpinan berdasarkan kecerdasan emosi. Gramedia Pustaka Utama.

Greenhaus, J. H., \& Beutell, N. J. (1985). Sources of conflict between work and family roles. Academy of Management Review, 10(1), 76-88.

Handayani, A., Afiatin, T., \& Adiati, M. G. (2015). Studi eksplorasi makna keseimbangan kerja keluarga pada ibu bekerja. Prosiding Seminar Psikologi \& Kemanusiaan( 2015 Psychology Forum UMM.

Huda, A. S. I., Prihatini, D., \& Paramu, H. (2019). Pengaruh Manajemen Konflik Peran Ganda, Pelatihan, Kesehatan dan Keselamatan Kerja Terhadap Perawat Wanita (Studi Kasus di RSUD BLAMBANGAN Banyuwangi). E-Journal Ekonomi Bisnis Dan Akuntansi, 6(2), 181-185.

Mangkunegara, A. (2012). Evaluasi kinerja SDM. Bandung: Refika Aditama.

Marga, C. P. W., \& Sintaasih, D. K. (2017). Pengaruh Konflik Kerja-keluarga dan Stres terhadap Physical Withdrawal Behaviour. Udayana University.
Mulyasari, I. (2019). Pengaruh kecerdasan emosional dan kompetensi terhadap kinerja pegawai. Journal of Management Review, 2(2), 190-197.

Nofriyaldi, S., \& Ratnaningsih, I. Z. (2020). Hubungan antara kecerdasan spiritual dengan work-family balance pada perawat wanita Ruang Rawat Inap RS. X Semarang. Empati, 7(2), 633-639.

Nursalam. (2014). Managemen Keperawatan!: Aplikadi dalam Praktik Keperawatan Profesional. Salemba Medika.

PPNI. (n.d.). UU No. 38 Tahun 2014.

Rosiano, M. W., Hardjajani, T., \& Yusuf, M. (2015). Hubungan antara Kebutuhan Aktualisasi Diri dengan Stres Kerja pada Perawat Wanita Berperan Ganda di RSUP Dr. Soeradji Tirtonegoro Klaten. Wacana, 7(1).

Sari, D. F. (n.d.). Pengaruh Konflik Peran Ganda Terhadap Stres Kerja Pada Karyawan Wanita Di Dinas Pertanian Provinsi Sumatera Utara.

Sim, K., Bujang, S., \& Ahmad, R. (2009). Work-family interface: The relationship between work-family and religious support and its influence on job, family and life satisfaction. Proceedings of Business and Information Volume 6, Issue 1, 2009.

Suryalaga, Y. L. (2020). Hubungan konsep diri dengan efikasi diri pada Pasien TB Paru di Wilayah Kerja Puskesmas Wonosari. Jurnal Keperawatan Profesional, 8(2), 69-81.

Susanto, K. (n.d.). Analisis Konflik Peran Ganda, Stres Kerja Dan Komitmen Organisasi Terhadap Kinerja Dosen Wanita Di Fakultas Ekonomi Dan Bisnis Universitas Jember.

Tri Ismu Pujiyanto, S. H. (2020). Performance enhancement of Nurse with Quality of nursing work life model. International Journal of Psychosocial Rehabilitation, 24(7), 7736-7743. https://doi.org/https://doi.org/10.37200/IJPR/V24I7 /PR2700744erformance en. International Journal of Psychosocial Rehabilitation, 24(7), 7736-7743. https://doi.org/https://doi.org/10.37200/IJPR/V24I7 /PR2700744

Vaughan-Johnston, T. I., \& Jacobson, J. A. (2020). Self-efficacy Theory. The Wiley Encyclopedia of Personality and Individual Differences: Models and Theories, 375-379.

Yunita, S., \& Fauziah, N. (2017). Hubungan antara kecerdasan emosional dengan konflik peran ganda pada Ibu yang bekerja di PT. Rajawali Nusindo dan PT. PHAPROS TBK Jakarta. Undip. 